\title{
CHANGES IN THE SPATIAL ORGANISATION OF FRUIT GROWING AT THE BEGINNING OF THE 21ST CENTURY: THE CASE OF GRÓJEC POVIAT (MAZOVIA VOIVODESHIP, POLAND)
}

\author{
Marcin Wójcik, AnNa TraczyK \\ Faculty of Geographical Sciences, University of Łódź, Poland
}

Manuscript received: December 19, 2016

Revised version: February 22, 2017

\begin{abstract}
Wójсік M., TRAсZYK A., 2017. Changes in the spatial organisation of fruit growing at the beginning of the 21st century: The case of Grójec poviat (Mazovia voivodeship, Poland). Quaestiones Geographicae 36(2), Bogucki Wydawnictwo Naukowe, Poznań, pp. 71-84, 9 figs.

AвSTRACT: This paper is meant to determine trends in changes in the organisation of fruit production at the beginning of the 21st century. It focuses on the determination of those trends as well as their circumstances. The analysis of changes in the organisation of fruit production was made using Grójec poviat as an example. The accession of Poland to the European Union resulted in the intensification of processes of specialisation and concentration in agriculture, due to which the area occupied by orchards started to grow systematically. With the growing area and the intensification of fruit crops, quantities of fruits produced also increased. Currently, Poland is one of the biggest fruit manufacturers in Europe, with Grójec poviat being the biggest producer in Poland.
\end{abstract}

KEY wORDS: fruit growing, EU accession, agricultural policy, Grójec poviat, Poland

Anna Traczyk, Marcin Wójcik, Faculty of Geographical Sciences, University of Łódź, ul. Kopcińskiego 31, 90-142 Łódź, Poland; e-mail:anna.traczyk@geo.uni.lodz.pl, marcin.wojcik@geo.uni.lodz.pl

\section{Introduction}

Fruit growing is a branch of agriculture undergoing an intensive transformation in modern conditions. Changes in this sector started in the 1990s with the transition from a centrally planned to a market economy (Kacprzak 2002, Hubbart et al. 2007). At the beginning of the $21^{\text {st }}$ century its pace accelerated, mainly due to Poland's accession to the European Union and the change of the previous economic conditions (Czernyszewicz, Adamska 2008; Roman, Nuszkiewicz 2013; Wigier 2014).

The processes of globalisation and harmonisation of agricultural policies in the EU member states have special significance for the formation of specialisation in agriculture, due to regulations related to the impact of instruments of the Common Agricultural Policy (CAP) (Balmann et al. 2006). The growing competition in global markets has caused a fundamental revision in thinking about development methods that varied economically in the new member states (Kiss 2011; Csaki, Jambor 2009). Specialisation of farms became an indispensable element of agricultural transformation in such countries as Poland, as it resulted in their increased productivity and profitability. Works concerning structural changes in agriculture in long-time member states have shown that specialisation has been 


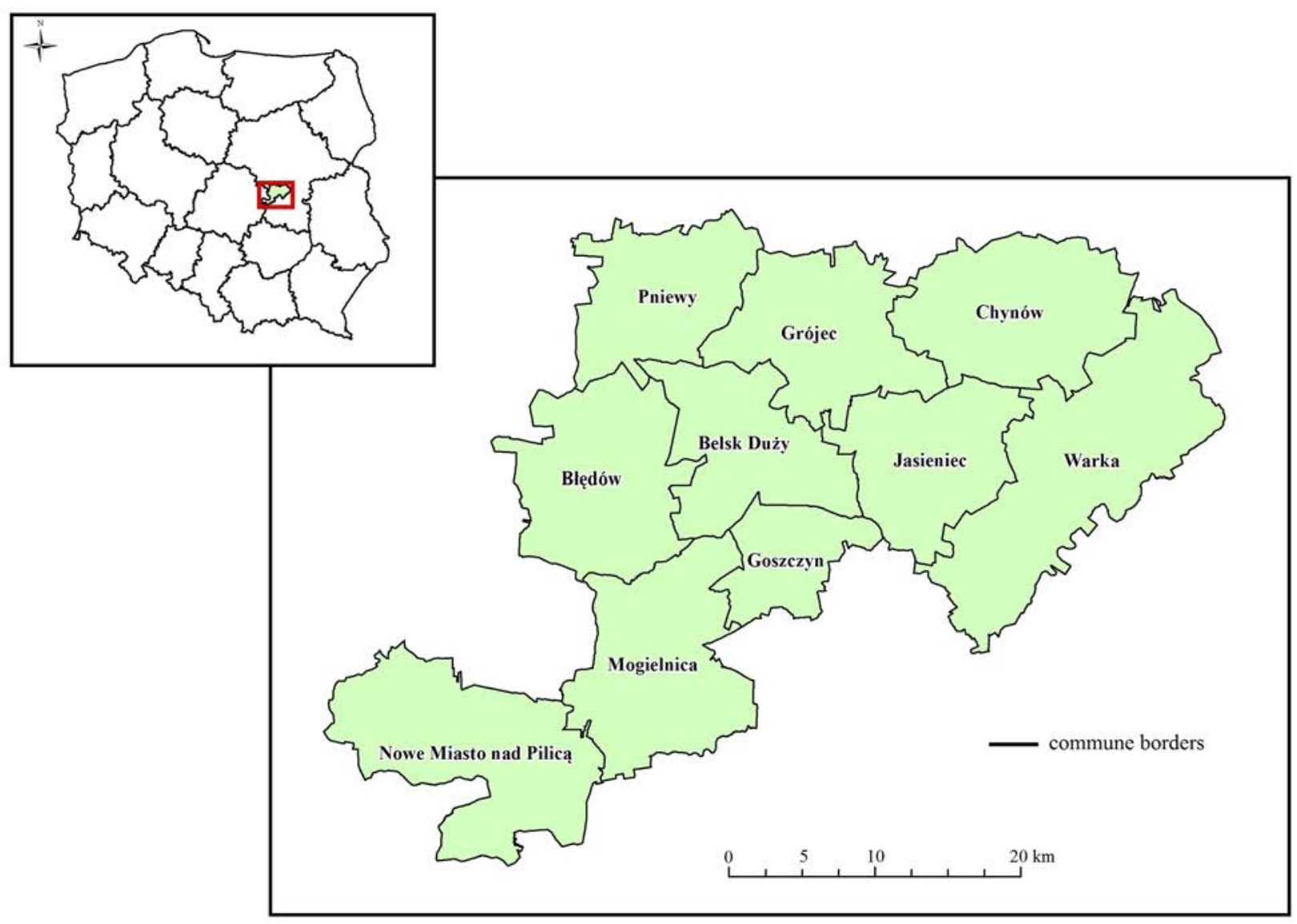

Fig. 1. The location and administrative division of Grójec poviat. Source: own study based on Centre of Geodetic and Cartographic Documentation data.

one of the most important factors of influence of the support instruments for the agricultural sector (Mora, San Juan 2004). Over 10 years after the big expansion of the European Union, which mostly included the countries in Central and Eastern Europe, these effects can be seen in the production structure of the region (Vosta 2012; Czyżewski, Smędzik-Ambroży 2015). This is significant for the changes in the spatial structure of permanent crops, especially for the important Polish specialisation in this regard, namely fruit production (Gołasa 2014, Pizło 2011). As far as spatial transformations are concerned, these effects are related to a relatively quick change in land use (Rabbinge, Diepen 2000).

The accession resulted in a number of changes in the agricultural sector. One of the conditions necessary for the functioning of the single European market and achieving good production results was an increase in the level of specialisation in agriculture, as well as its adaptation to new economic conditions (Wicki 2005; Bladford, Hill 2005). The intensification of the processes of specialisation in agriculture after the accession resulted in an increase in the number of farms focusing on one direction of production, which in turn sparked an increase in the number of farms specialising in fruit production in Grójec poviat. In 1996, there were 7,422 fruit farms in the poviat, this number having grown to 10,439 by 2010 (Skórnicki 1998, Agricultural Census 2010). Following the growing number of fruit farms, the area taken by fruit trees and shrubs also increased. Changing economic conditions resulted in a transformation in the organisation of orchard production. The changes could be seen not only in the production system itself, but also in the organisation of sales. The process of transformation in the fruit sector was helped by EU programmes that significantly accelerated it (Izdebski et al. 2012).

Grójec poviat is the largest area of concentration of orchard production in Poland, specialising in the production of apples. It is located in the south-western part of Mazovia voivodeship (Fig. 1). The poviat includes 10 communes, including 
4 urban-rural ones (Grójec, Mogielnica, Warka and Nowe Miasto nad Pilica), as well as 6 rural ones (Belsk Duży, Błędów, Chynów, Goszczyn, Jasieniec and Pniewy).

Orchard production in Grójec poviat benefits from favourable climate and soil conditions, as well as convenient location in relation to a large and receptive market of Warsaw and Łódź. Moreover, the area has long orchard traditions that date back to the 16th century (Pieczyński 1996).

\section{The aim of the study, sources of data and methods}

The aim of this paper is to determine changes in the spatial organisation of fruit production in Grójec poviat at the beginning of the 21st century, as well as the conditions of this process. First, historical, political and economic circumstances of the development of fruit production in the poviat are presented. The main part shows the transformation of the land use structure as well as production effects during the transition as a result of the CAP.

The source materials used in the paper can be divided into several groups. The first is the literature on the subject which was used to explain the origin of fruit production in Grójec poviat, as well as to point to the most important factors determining the transformation in fruit production. Desk research also allowed obtaining the necessary information concerning trends in the transformation in fruit production as an effect of Poland's accession to the European Union. The second group of materials includes statistical data collected in the Local Data Bank of the National Statistical Office, in the FAOSTAT base. On the basis of the 1996 and 2010 agricultural censuses, changes in the size structure of farms were analysed as well as the area occupied by orchards in Grójec poviat. Agricultural Statistical Yearbooks were also an important source of information used to analyse changes in purchase prices of chosen fruits in Poland between 2000 and 2012.

The third group of materials embraced cartographic studies. Analyses of the spatial distribution of orchards in Grójec poviat in 1990 and 2006 were conducted on the basis of the Corine
Land Cover map developed by the European Environment Agency.

The fourth group of materials included survey interviews with fruit producers on selected fruit farms in Grójec poviat in 2014. Social studies were made in all the communes of Grójec poviat, namely Belsk Duży, Błędów, Chynów, Goszczyn, Grójec, Jasieniec, Mogielnica, Nowe Miasto nad Pilica, Pniewy, and Warka. A total of 208 interviews were conducted with the owners (or managers) of fruit farms. $2 \%$ of farms in Grójec poviat were included in the study. Surveys were conducted in towns with a high concentration of orchards. The biggest group of farms included in the social study embraced those between 5 and 10 ha (35\% of all farms surveyed), and between 10 and 15 ha (32\%). Some $8 \%$ of farms had between 1 and 5 ha, with approximately $25 \%$ exceeding 15 ha.

\section{Origins of the development of fruit production in Grójec poviat}

The tradition of fruit growing in the Grójec region dates back to the 16th century. It started during the reign of king Sigismund the Old and his wife queen Bona, known for her passion for gardening (Skórnicki 1998). In 1545, Bona received a large tract of land where she founded new villages and promoted fruit growing among the people (Słowińska 2007). At her insistence, the first orchards were set up in Kozietuły, Błędów, Stara Wieś, Lipie and Belsk (Pachocki 1997).

In the 16th, 17th and 18th centuries, fruit trees and shrubs were only planted near buildings. Such orchards were small, they usually did not exceed 1-1.5 ha. Plums, apples, pears, cherries and sweet cherries were grown, while shrubs included hazel, gooseberries and currants. The cultivation of fruit plants did not gain economic importance until the end of the 19th century when the first commercial orchards were set up. Production for one's own needs was replaced by distribution-oriented production. The first commercial orchards in the Grójec region were created in the years 1880-1890. From then on, fruit trees were not only planted behind buildings, but also in the fields (Słowińska 2007). The clergy, famous for their passion for horticulture, are credited with contributing a lot to the development 
of fruit production. They employed local people in their monastery gardens, teaching them to care for and propagate fruit trees and shrubs (Jankowski 1923).

Initially, the cultivation of fruit plants was concentrated in several areas in the poviat, such as those around Góra Kalwaria, Czersk, Błędów and Grójec (Goldberg 1939). With time, the area taken by orchards kept gradually increasing. Until the 1950s, the level of development of fruit production was low. It was "extensive, fragmented, scattered and non-specialised, with random varieties and a low agrotechnical culture", which resulted in "low yields, wrong assortment of fruits and their low quality" (Kubiak 1998: 10).

The foundation in 1951 of the Institute of Pomology and Floriculture in Skierniewice, headed by Prof. Szczepan Pieniążek, was a landmark event. Since its establishment, scientists have worked with growers from Grójec poviat, giving them a wide knowledge on starting, running and protecting their orchards (Pachocki 1997). Major achievements in the development of fruit growing in Grójec poviat are attributed to Prof. Pieniążek himself. It was his work that transformed the orchards in Grójec poviat in the American fashion - from sparse and tall into dense and low (Słowińska 2007).

In the second half of the 20th century, fruit growing in Grójec poviat began to develop rapidly. This was caused by a number of factors, most importantly advances in pomology. The cooperation between scientists and growers resulted in the introduction of new varieties to the structure of crops, the dissemination of new production technologies and means of protecting orchards, which directly influenced the growing area taken by them (Kacprzak 2005). Also actively working in this period, agricultural cooperatives contributed to the development of this branch of farming (Kulikowski 2007).

Grójec poviat is now the biggest area of concentration of fruit production in Poland. The development of fruit production here is helped by both, favourable climate and soil conditions. The poviat has a specific microclimate characterised by high temperature differences between the day and the night from mid-September to late October. Such wide fluctuations in this period are beneficial to the physiological processes in fruits just before harvest. They accumulate more sugars, which in turn translates into their appearance and taste (Pieniążek 1965). The only climatic factor unfavourable to fruit production is the relatively low annual rainfall, and thus periodic water shortages, supplemented by artificial irrigation. Fruit production is also helped by good soil conditions. Podsols dominate in the region, allowing the cultivation of virtually all kinds of fruit trees and shrubs. On podsolic soils fruit plants grow well and give high yields (Pieniążek 1965). In addition to the natural conditions, fruit growing in the region also benefitted from its convenient location. Grójec poviat is located approximately $50 \mathrm{~km}$ from Warsaw and about 100 $\mathrm{km}$ from Łódź. These cities are the main markets for fruit producers in this area. The increase in the concentration of orchards is also supported by local fruit-growing traditions (Pieczyński 1996).

\section{Political, economic and social conditions for the change in the organisation of fruit-growing at the beginning of the 21 st century}

The beginning of the 21st century is a period of many changes in the organisation and operation of the fruit production sector, caused by changes in the previous economic conditions. Their pace and directions have been influenced by a number of factors, including political, economic and social ones.

Agricultural policy is a key driver of changes taking place in farming, including fruit production. The state uses direct means (such as taxes, tariffs, price control, subsidies) and indirect ones (such as credit interest regulations) to influence the agricultural sector, thus determining its development rate (Hunek 2000). As in other branches of agriculture, fruit growing requires the state's support since the return on the cost of investment is not quick, and the production process depends on natural factors (Smoleń, Górniak 2007). The size, quality and structure of production depend, on the one hand, on the natural circumstances stemming from location, and on the other, on weather (Żmija 2011). The need to support agricultural manufacturers is also dictated by work efficiency lower than in other professions, which in turn translates into lower incomes gained by 
this group (Smoleń, Górniak 2007). According to researchers studying fruit production, agricultural policy is one of the most important factors that support the processes of transformation in the sector (Kacprzak 2002). The modernisation of farms and the adaptation of the production system to the increasing requirements involve large sums of money that the producers themselves often cannot provide, making financial support from outside all the more important (Lange et al. 1996).

Polish accession to the European Union has changed the way in which the agricultural sector is financed. It has opened new opportunities for obtaining funds for the development and modernisation of farms. Since 2004, Polish agricultural producers, including fruit growers, have had an opportunity to use the instruments provided by the CAP in the form of direct subsidies and financial means offered as part of the EU assistance programmes (Nosecka 2005). The first programme intended for farming, including fruit growing, was the Special Accession Programme for Agriculture and Rural Development - SAPARD, available between 2002 and 2006 (Skórnicki 2003). After Poland's accession to the Union, fruit growers could obtain financial support from the following assistance programmes: the Rural Development Plan for 2004-2006, the Sectoral Operational Programme "Restructuring and Modernisation of the Food Sector and Rural Development" in force in the years 2004-2006, as well as the Rural Development Programme for 2007-2013 (Czernyszewicz, Adamska 2008).

European Union programmes were an important source of financing investments on the surveyed fruit farms. 55\% of respondents used some form of support offered by the programmes. 35\% of the farms under study benefited from the biggest ones, 2004-2006 RDP and 2007-2013 RDP. SAPARD also played an important role in the financing of investments since it was used by $18 \%$ of the respondents. The 2004-2006 RDP and 20072013 RDP were the main sources of investment financing on farms between 10 and 20 ha $(60 \%$ of beneficiaries), while the SAPARD programme was mainly used by farms bigger than 15 ha $(71 \%)$. Only about $3 \%$ of farms benefited from subsidies under the Sectoral Operational Programme "Restructuring and Modernisation of the Food Sector". Subsidies offered as part of the EU programmes were an important tool that accelerated the modernisation of farms in Grójec poviat and their adaptation to the new circumstances.

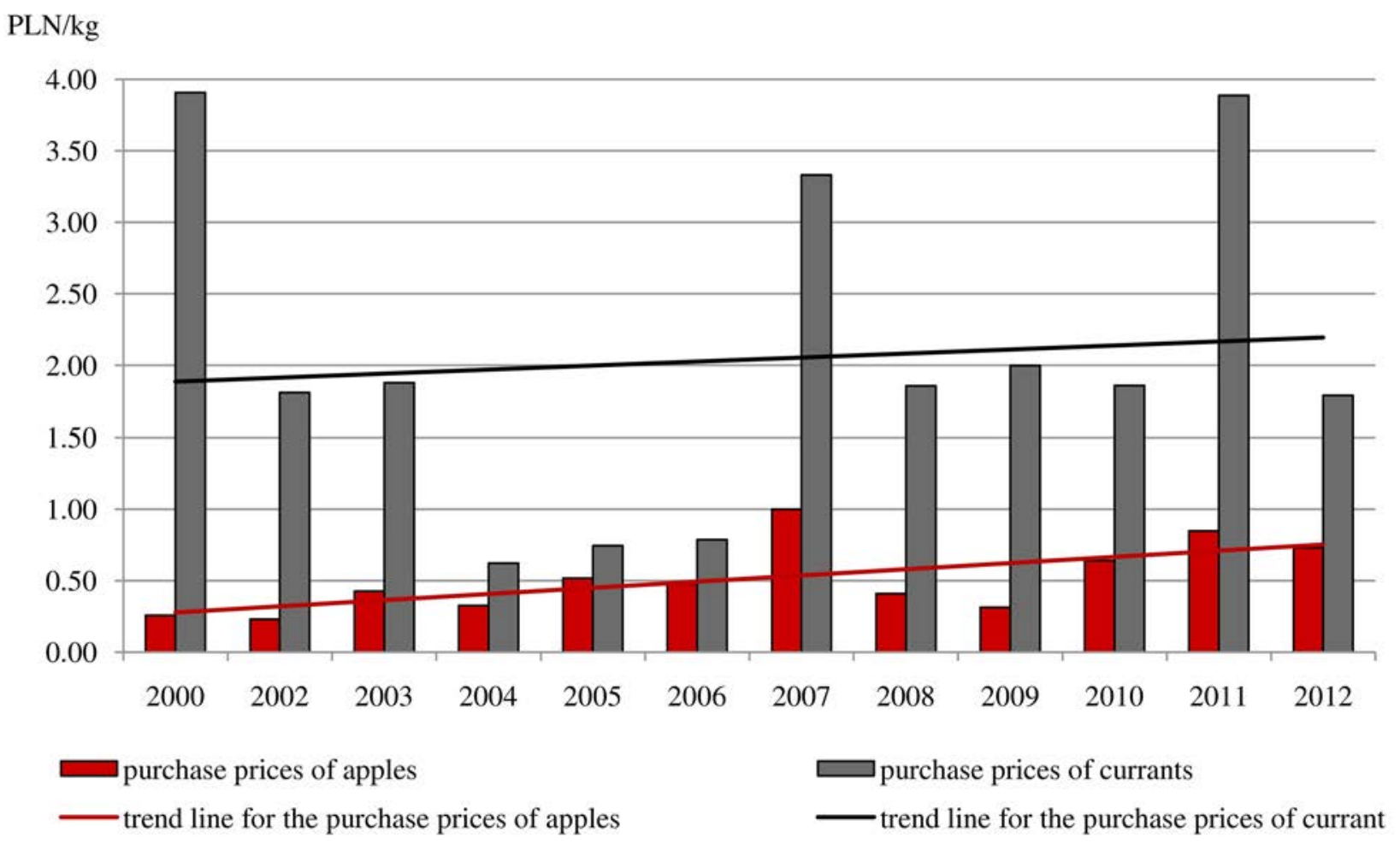

Fig. 2. Average purchase prices of apples and currants in the period 2000-2012. Source: own calculations based on the 2007, 2009, 2011 and 2013 Statistical Yearbooks of Agriculture. 
Economic conditions also have an important impact on the transformation of the organisation of fruit growing. One of the key economic factors that determine the transformation in this regard is the profitability of production, expressed in a relation between the sale price and the production cost (Kacprzak 2002).

Between 2000 and 2012, the price of fruit underwent repeated fluctuations (Fig. 2). There were periods when production was highly profitable and years when the cultivation of certain kinds was almost or completely unprofitable. Meanwhile, the costs of production were steadily growing due to the dynamic increase in the prices of the means of production - machines, plant protection products, fertilisers, and fuel (Izdebski et al. 2012). Despite price fluctuations, fruit production remained profitable throughout this period. The cultivation of apples, pears, cherries and sweet cherries was the most profitable, while currants, plums and strawberries were less so (Makosz 2014).

Fruit farmers from Grójec poviat asked in the survey for their opinion on the profitability of fruit production mostly stated that it was profitable. About 32\% thought that fruit production was quite profitable, while $7 \%$ indicated that the profits were low. Only 2 growers said that the cultivation of fruit trees and shrubs was unprofitable (Fig. 3).

Positive responses came from farmers running large and medium-sized farms, while the owners of small ones, mostly dominated by currants, aronia and strawberries, were usually less optimistic. Profitability of production was one factor that fostered the growth in the area occupied by orchards as well as changes in the production technology and fruit storage on fruit farms in Grójec poviat.

Economic factors important for the organisation of fruit production also include the level of consumption of fruits and fruit products. The consumption and consumers' preferences concerning their kinds, varieties and quality result in changes to the structure of cultivated fruits and their production. They also cause spatial changes reflected in an increase in the area occupied by orchards and berry farms (Kacprzak 2002).

Since the beginning of the 21st century, the amount of fruit consumed in Europe has been steadily growing, while the consumption of processed fruit remains roughly the same. In 2001, the average European consumed about 77.5 kilograms of fruit per year, while in 2011 about $13.5 \mathrm{~kg}$ more than in 2001 (FAOSTAT). Apples and pears are the dominant group of fruits consumed in Europe (Freshfel Fruit ... 2012). With approximately 21 litres consumed by an average European annually, juices and nectars are the biggest groups of consumed processed fruit products (AIJN 2010, 2012).The relatively high level of consumption of fresh and processed fruit in the period favoured the development of fruit production and the transformation of its organisation.

The pace and directions of the transformation in fruit production are also heavily influenced by social circumstances, with the education and

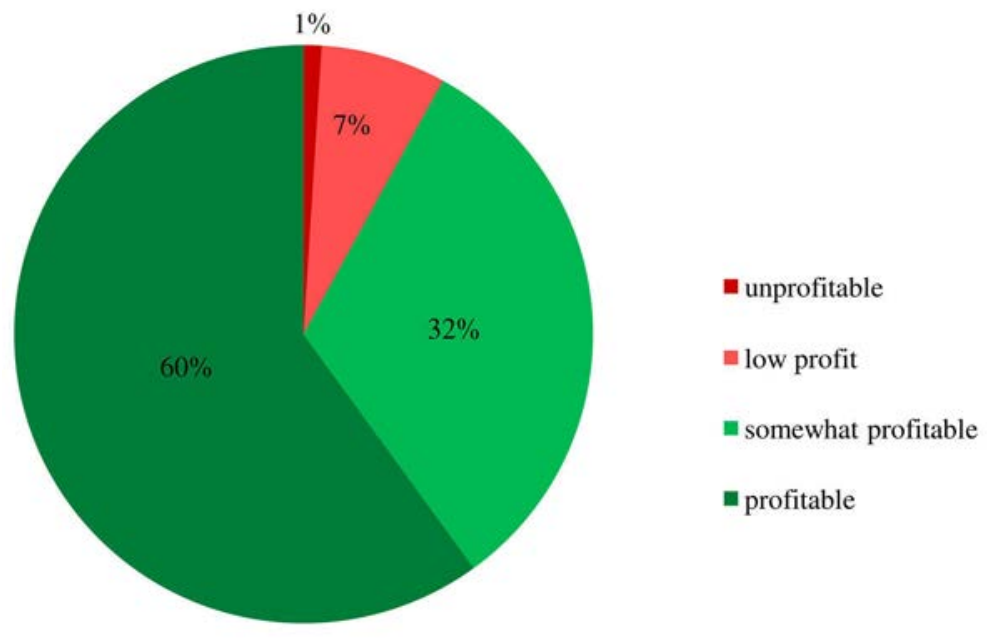

Fig. 3. Structure of responses to the question about the profitability of fruit production. Source: survey results. 

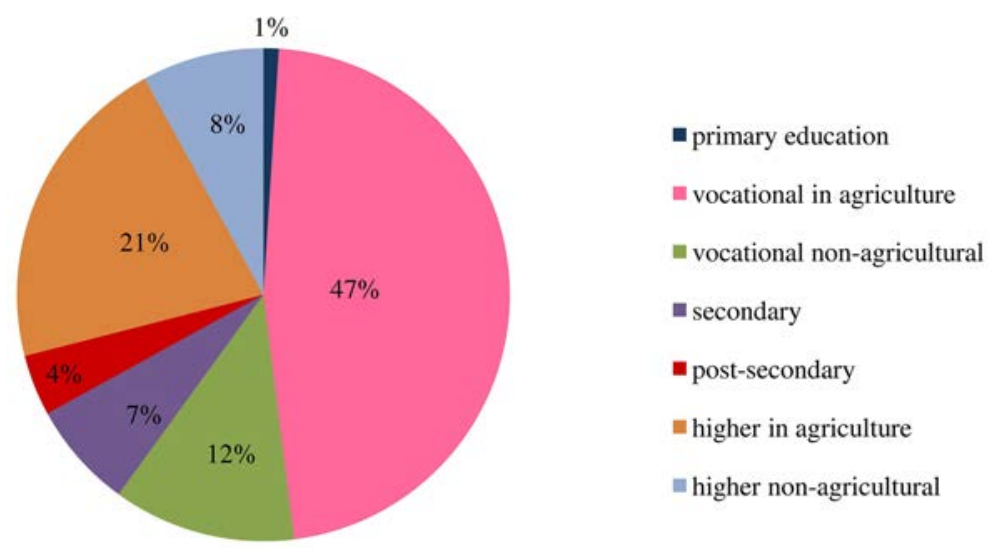

Fig. 4. The educational structure of the respondents.

Source: own study.

age of farm owners playing the most important roles. These factors determine the effectiveness of work on the farms, and thus their production performance (Bański, Stola 2002). Farms managed by people with better professional qualifications generally perform significantly better than those run by persons without adequate education. Besides, their owners are more willing to expand their orchards and implement new production technologies. Farms headed by persons with high professional qualifications reach for outside sources to finance their modernisation more often than those administered by people with lower levels of education (Czapiewski, Janc 2009). The situation is similar in the case of age. In general, production performance is much better on farms managed by young or middle-aged people than on those run by people older than 60 (Kacprzak 2002).

According to a survey of fruit farmers in Grójec poviat, their vast majority had appropriate professional qualifications. Almost half of the respondents had vocational education in agriculture, with $21 \%$ having higher education in this field (Fig. 4). Among the group declaring vocational education, farmers between 41 and 60 dominated $(70 \%$ of respondents with vocational education in agriculture), while most people with higher education were aged 26 to 40 (88\% of the respondents with higher education in agriculture). Approximately $32 \%$ of the respondents did not have agricultural education.

Age and education are factors influencing the change in fruit production, yet they do not constitute a barrier to its development (Kacprzak 2002). Having proper education is conducive to farm management and high yields. Age affects the effectiveness and level of utilisation of modern production technologies, with young and middle-aged farmers being more likely to benefit from them.

\section{Transformation of the spatial structure in fruit growing}

Fruit growing is a rapidly developing branch of agriculture. Since the early 21st century, the spatial structure of fruit production in Grójec poviat has been undergoing an intensive transformation caused by a rapid increase in the area occupied by orchards and changes in the organisation of production.

In the years 2000-2010, the area occupied by orchards in Grójec poviat kept steadily increasing. In 2000, fruit trees and shrubs were grown on 35,106 ha, while in 2010 the area was 54,191 ha (an increase of 35\%). The biggest increase could be seen between 2005 and 2010, when the area grew by $26 \%$ (Local Data Bank). This rapid development of fruit growing in the poviat was due to numerous factors. One of them, after 2005, was the changing economic conditions after Poland had joined the European Union. Since 2004, Polish fruit producers have had an opportunity to obtain CAP instruments offered as part of assistance programmes. Access to the EU funds allowed the financing of numerous investments on farms, so that farmers were more willing to start fruit production or expand their acreage (Izdebski et al. 2012). It should be emphasised that the rapid development of fruit production in this region, 


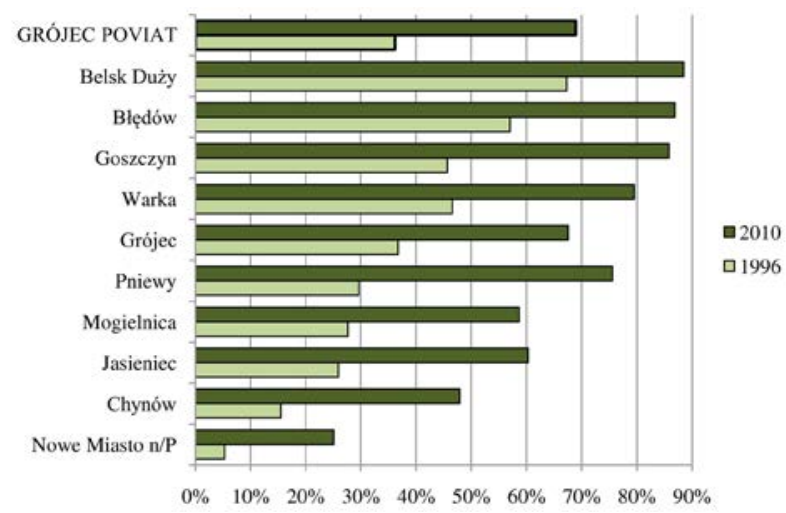

Fig. 5. The proportion of orchards in the structure of agricultural land in Grójec poviat and its communes in 1996 and 2010.

Source: own calculations based on the 1996 and 2010 Agricultural Censuses.

resulting in the expanding area of fruit farms, was also a result of continuing local traditions and imitation (Kacprzak 2002). Seeing that fruit growing was far more profitable than cereals, even on a small acreage, farmers decided to start orchards.
In 1996, arable land dominated the farmland in Grójec poviat, taking up $44 \%$ of its total area. Orchards occupied 36\% of it. Belsk Duży, Błędów, Warka and Goszczyn had the highest proportion of orchards in their structure. Orchards amounted to over $45 \%$ of the structure in those communes (Agricultural Census 1996). In 2010, orchards were the dominant type of agricultural land in Grójec poviat. Fruit trees and shrubs took up $69 \%$ of the farmland and were the dominant type in all communes of the poviat, with the exception of Nowe Miasto nad Pilica (Fig. 5). Belsk Duży, Błędów, Goszczyn, Warka, Pniewy and Grójec had the biggest share of orchards in their agricultural land, even over 65\% (Agricultural Census 2010).

A detailed analysis of changes in the spatial distribution of fruit crops in the communes of Grójec poviat shows that each of the administrative units under study saw a significant increase in the area occupied by orchards. In the study period, the proportion of orchards in the structure of farmland

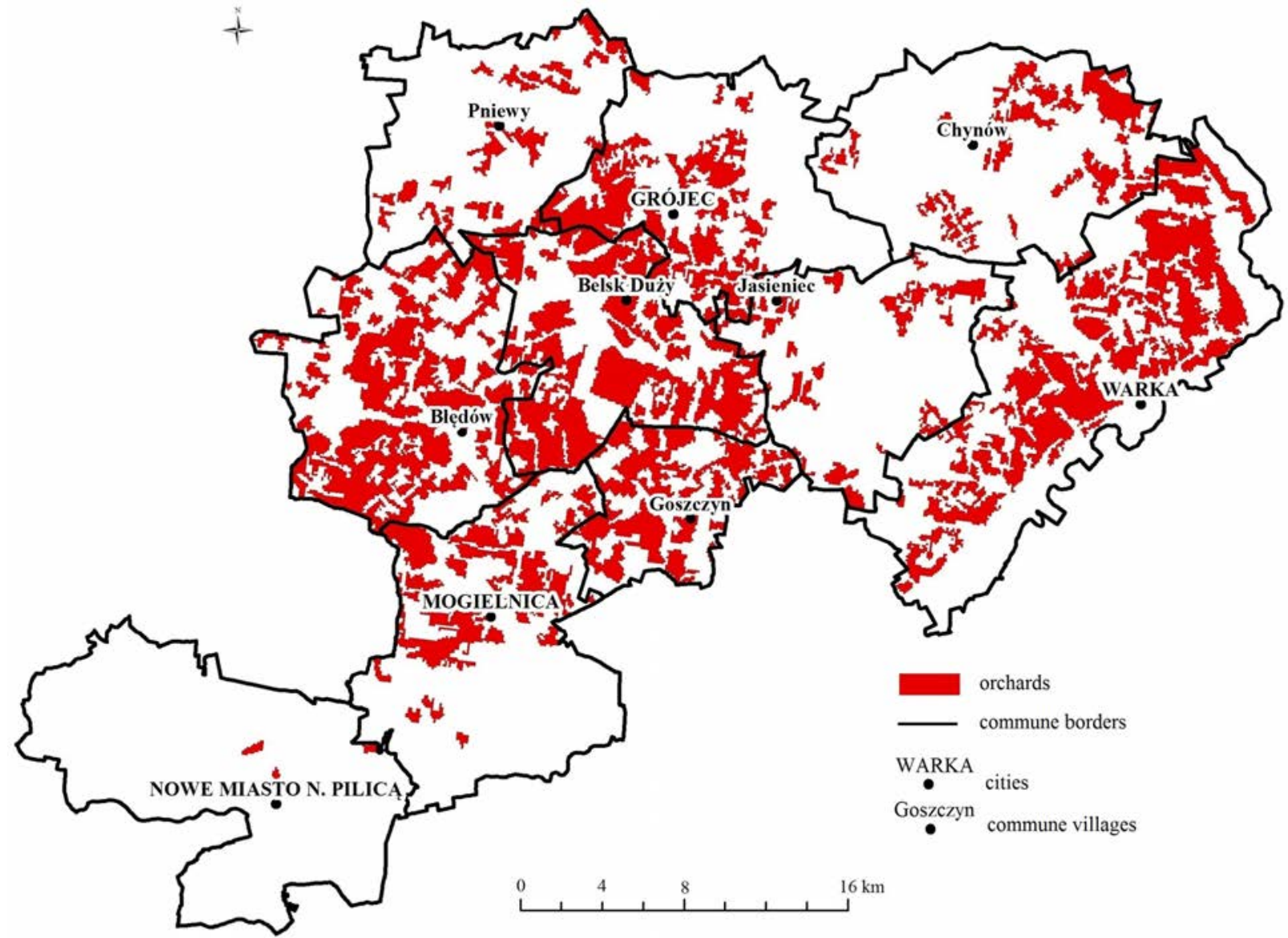

Fig. 6. Distribution of orchards in Grójec poviat in 1990. Source: own study based on Corine Land Cover 1990. 


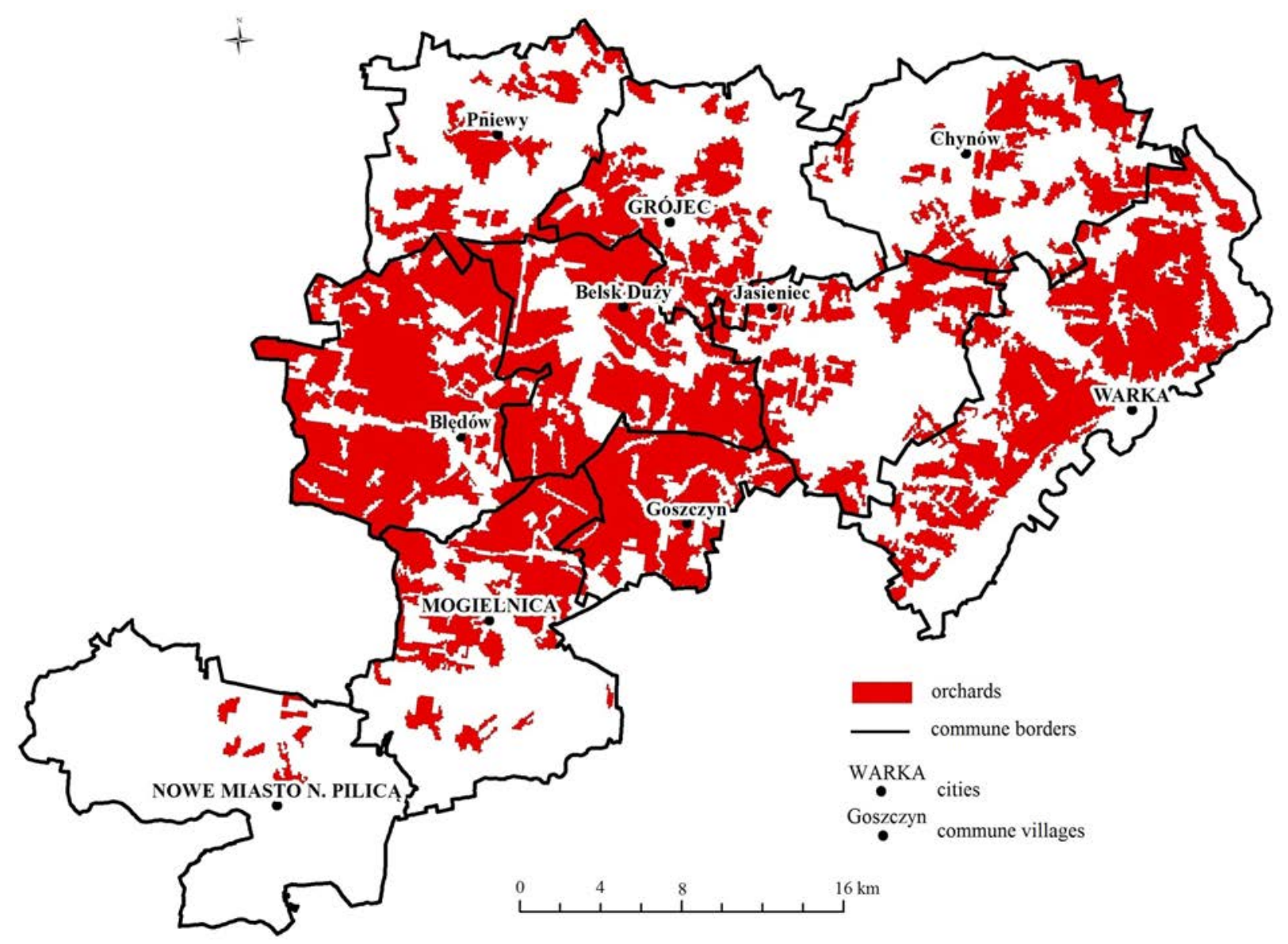

Fig. 7. Distribution of orchards in Grójec poviat in 2006. Source: own study based on Corine Land Cover 2006.

grew from $36 \%$ in 1996 to $69 \%$ in 2010 . The biggest changes in the structure of land use occurred in Goszczyn and Pniewy communes, where the area occupied by orchards had doubled. In six of the ten communes, namely Błędów, Chynów, Grójec, Jasieniec, Mogielnica and Warka, the share of orchards in the overall structure of land use grew by over 1/3. In Belsk commune in 2010, the area occupied by orchards was about $25 \%$ higher than in 1996. The smallest increase in the area occupied by fruit trees and shrubs in this period could be seen in Nowe Miasto nad Pilica, where the share of orchards grew from 5\% in 1996 to $25 \%$ in 2010.

In 1990, the communes of Błędów, Belsk Duży, Goszczyn, Warka and Grójec had the highest number of orchards. A large concentration of fruit crops could also be found in the northern part of Mogielnica. Local orchards also grew in Pniewy, Chynów and Jasieniec. The only commune in the area virtually uninvolved in fruit growing at the start of the 1990s was Nowe Miasto nad Pilicą (Fig. 6).
In 2006, fruit production also started developing in areas where it had not been practised before, including Nowe Miasto nad Pilicą. During this period, the area taken up by orchards grew in all the communes of Grójec poviat (Fig. 7).

In the analysed period, there was a significant increase in the area occupied by orchards, both in the communes where they were scarce and in those where they took up significant portions of land. The high concentration of fruit crops in the communes of Błędów, Belsk Duży, Warka and Goszczyn mostly stems from the deep-rooted fruit growing traditions, dating back in Grójec poviat to the 16th century. These communes were the first centres where fruit trees and shrubs were grown. In other communes, fruit production developed as an imitation.

At the beginning of the 21st century, the size structure of individual farms also changed. In $1996,46 \%$ of all farms were small, below 5 ha, with $39 \%$ of farms between 5 ha and 10 ha and $11 \%$ from 10 ha to 15 ha. Only $4 \%$ of farms exceeded 15 ha. 


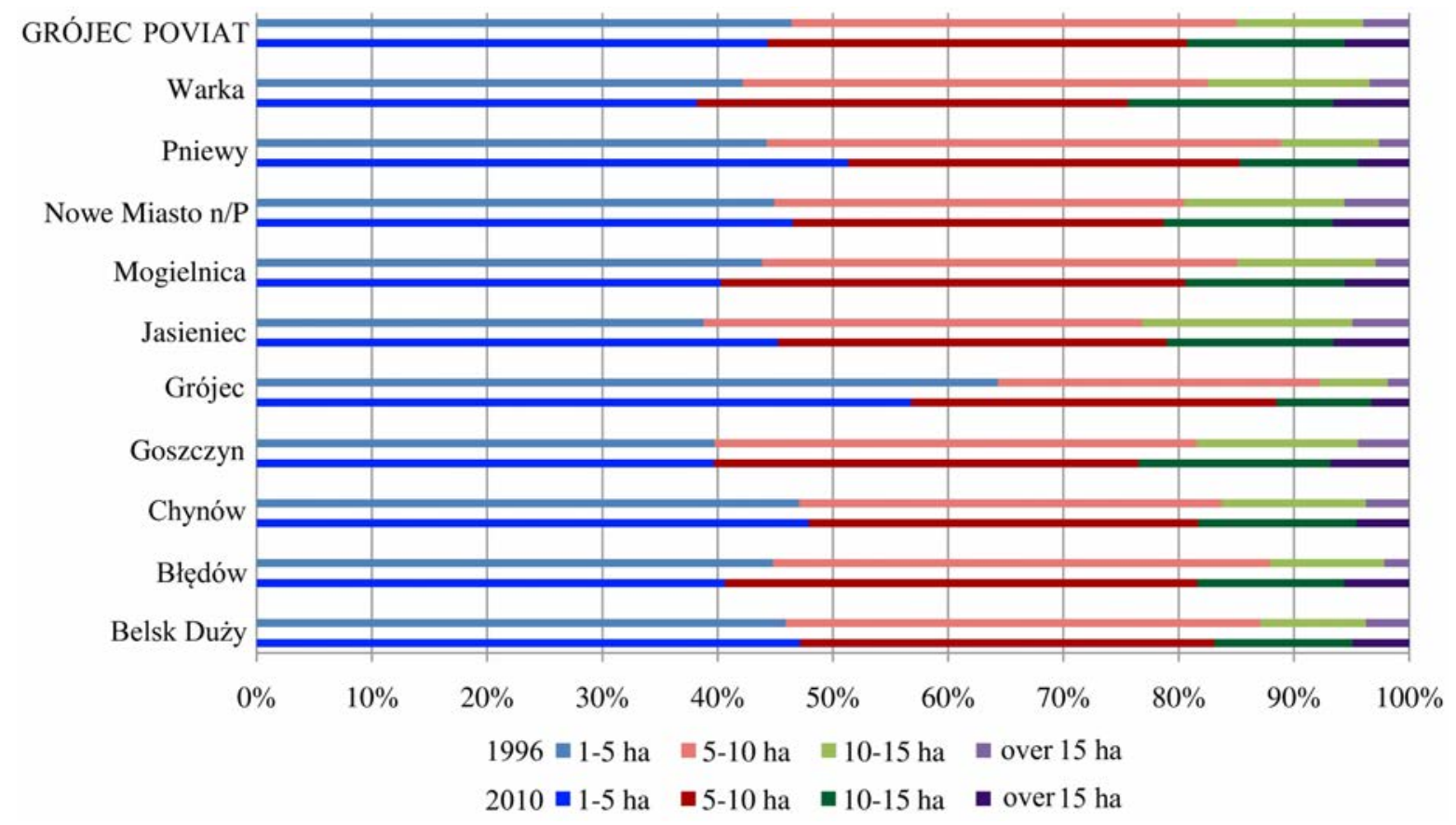

Fig. 8. Size structure of individual farms in the communes of Grójec poviat in 1996 and 2010. Source: own compilation based on Agricultural Census 1996 and Agricultural Census 2010.

Grójec had the biggest proportion of small farms (64\% of individual farms). In other communes, the proportions of farms sized 1-5 ha and 5-10 ha were similar. Most farms over 10 ha were located in Jasieniec, Nowe Miasto nad Pilicą, Goszczyn and Chynów (Agricultural Census 1996).

In 2010, 44\% of farms were small, below 5 ha, with $36 \%$ between 5 ha and 10 ha and 14\% from 10 ha to 15 ha, and $6 \%$ of farms exceeding 15 ha (Fig. 8). The highest proportion of small farms (below 5 ha) could be found in Grójec (57\% of individual farms), Pniewy (51\%), Belsk Duży (47\%), Chynów (47\%), Nowe Miasto nad Pilicą (46\%), and Jasieniec $(45 \%)$. In other communes, the proportions of farms sized 1-5 ha and 5-10 ha were similar. Warka, Goszczyn, Jasieniec and Nowe Miasto nad Pilicą had the highest share of farms exceeding 10 ha (Agricultural Census 2010).

In the years 1996-2010 there was a slight transformation in the size structure of individual farms in Grójec poviat: the average size decreased from 7.1 ha in 1996 to 6.3 ha in 2010 (Agricultural Census 1996, 2010). Small farms below 5 ha were still dominant, but the proportion of those exceeding 10 ha had grown.

The size structure is one of the factors determining the level of efficiency and marketability of farms (Bański, Stola 2002). Besides, it also influences the amount of income earned by the producers. Due to the changing economic conditions, the size needed to achieve a minimum income sufficient to support a family and make necessary investments also increases. In the centrally planned economy, fruit production was profitable even in orchards of 2 to 3 ha, while in 1990s researchers studying fruit production claimed that the cultivation of fruit trees and shrubs became profitable over 5 ha. Today, profit at the level of parity (i.e. comparable to the average wage in the national economy) is assumed to be possible at about 7 ha (Ziętara 2012).

The size structure of farms in Grójec poviat in the analysed period was not conducive to the development of fruit production. The dominant group consisted of small farms that often fail to provide an income sufficient to support the grower and their family, and to provide basic investment, despite being highly effective (Zegar 2009). The unfavourable size structure of farms notwithstanding, fruit growing in Grójec poviat is thriving and highly developed.

\section{Production results}

Since the beginning of the 21st century, the area occupied by orchards in Grójec poviat has been steadily increasing. The increase in the area 
taken up by fruit trees and shrubs is accompanied by the growing intensity of orchard production. By the end of the 1990s, there were on average 1,000 fruit trees per 1 ha of land. In modern orchards created after 2000, there were up to 4,000 trees per $1 \mathrm{ha}$, depending on the kind of tree (Makosz 2014).

The increase in the area and intensity of fruit production has boosted the amount of fruit produced. In 1994, the Grójec district produced a total of 596,300 tonnes of fruit, which grew to 934,600 by 2010 . Apple trees dominated the crop structure both before 2000 and in the first decade of the 21st century. In 1994, approximately 545,000 tonnes of apples were picked, and the number grew to 650,000 in 2002 and 900,000 in 2010. According to estimates, apples produced in Grójec poviat accounted for about $30 \%$ of the national production (Maliszewski 2004, Borowska 2013). Cherries and berries were also important. In 1994, the cherry harvest amounted to 8,200 tonnes, in 2002 - 10,000 tonnes, and in $2010-$ 12,100 tonnes. In 1994, 6,.600 tonnes of berries were picked, which increased by 1,500 in 2010 . Pears, plums and sweet cherries were not significant in the production structure of the poviat. In 1994, there were 3,600 tonnes of pears, 4,100 tonnes of plums and 1,800 tonnes of sweet cherries. In 2010, the poviat harvested 5,200 tonnes of pears, 6,000 tonnes of plums and 3,200 tonnes of cherries (Pieczyński 1996, Maliszewski 2004, Central Statistical Office).

The communes of Błędów, Belsk Duży and Warka played the biggest roles in fruit production in that period, with approximately $70 \%$ of total production coming from them (Fig. 9). These are areas with strong fruit-growing traditions, where the cultivation of fruit trees and shrubs has been maintained for generations. Nowe Miasto nad Pilica and Pniewy have a limited share in the overall fruit production in the poviat. In these communes, fruit growing developed relatively late as compared with the remaining areas of the poviat, so their share stayed low (Maliszewski 2004).

The beginning of the 21st century was a period of major changes in the system of fruit distribution. Developments in this area were initiated in the early 1990s with the introduction of a market economy. The switch to a market economy, followed by Poland's accession to the European

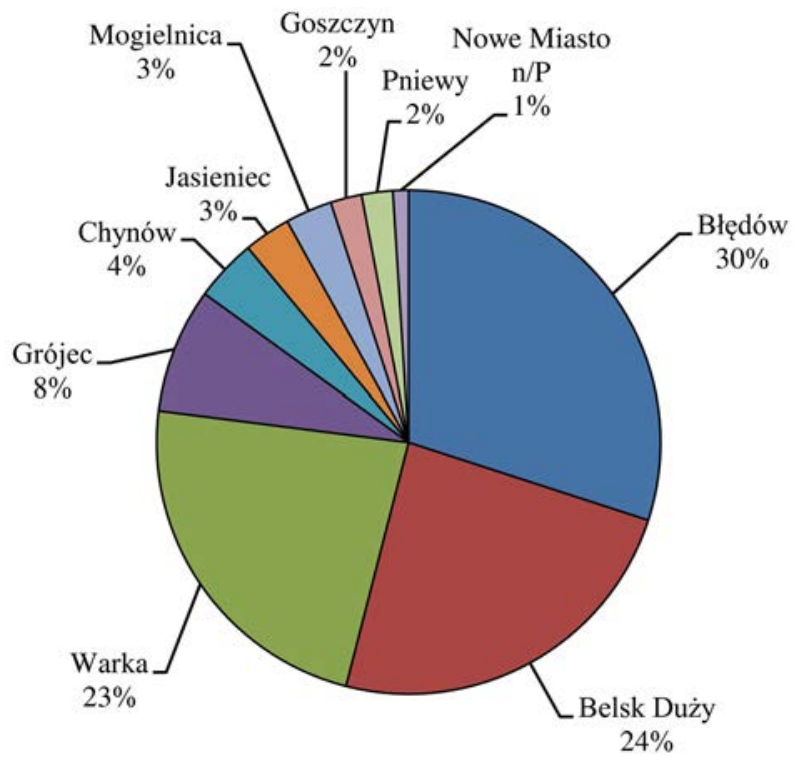

Fig. 9. Share of individual communes in fruit production in Grójec poviat.

Source: own calculations based on Maliszewski (2004).

Union, resulted in new opportunities and directions in fruit sales. Before the transformation, the main direction in fruit sales was cooperatives that handled further distribution. After 1990 and the disintegration of the existing system of organisation of the sale of agricultural products, wholesale markets where producers could sell to individual customers grew in prominence (Kacprzak 2002). After the country's accession to the European Union and the inclusion of fruit production in the $\mathrm{CAP}$, manufacturing groups and organisations able to negotiate higher prices and better conditions by delivering huge batches increased in significance. Moreover, by delivering their fruit straight to the market, they limited the number of brokers, allowing fruit growers to gain higher incomes. After 2004, the role of export also grew, as a new market emerged and barriers in foreign trade between EU members were dissolved. The lack of customs restrictions in the member states promotes the export of fruit and fruit products to the European markets (Płocharski 2003).

According to surveys, the dominant direction in the sale of fruit from farms located in Grójec poviat were purchasing centres. $98 \%$ of the respondents used this form of sale. Growers usually delivered their fruit to centres located near their places of residence or ones located no more than $5 \mathrm{~km}$ away. The second important direction was export through agents. Russia, Belarus, Moldova 
and Germany were listed most frequently as destinations of fruit from Grójec poviat. 56\% of the respondents sold their fruit on wholesale markets, mainly in Warsaw (84\% of growers selling on wholesale markets) and Łódź (24\%). Only 8\% of the respondents sold on the wholesale market in Radom, while 4\% went to Katowice. One in ten respondents delivered their fruit directly to processing plants. Plants in Warka, Łęczeszyce and Kozietuły were mentioned most often. In addition to the plants located in Grójec poviat, growers also sold their products to plants located in the vicinity of the poviat (including Tarczyn and Biała Rawska).

In terms of the share of individual directions of sale, ca. $55 \%$ of fruit were sold by growers in Grójec poviat to purchasing centres, $28 \%$ were exported, and $13 \%$ were sold on wholesale markets. Only about $4 \%$ of the fruit were delivered directly to processing plants. Only 10 respondents processed fruit on their own farms.

\section{Discussion and final conclusions}

Horticulture is a special segment of agriculture. Its planned development has to be based on long-term assumptions, including stable agricultural policies (see Hinton 1977, Galanopoulos et al. 2009). The permanent nature of crops, combined with the environmental requirements of this line of production, make fruit production highly vulnerable to changes in the environment, both man-made and natural. In the recent years, such elements as professional knowledge, support from Common Policy instruments and international politics have become important development factors. The research shows that the deepening specialisation has resulted in very good production and brought about significant changes in land use. The influence of the state's agricultural policy within the European Union has stabilised the production system while strengthening the single-function nature of agriculture in this region. In the case of permanent crops, this may result in certain economic risk, the negative effects of which may become apparent as a result of the disturbance of the balance, i.e. a rapid change in international exchange regulations. Despite these potential threats, the development of fruit production in Grójec poviat, as well as in other such areas in Poland, may be considered one of the successes of Polish agriculture.

The early 21st century was a period of many changes in fruit production, started in the 1990s by the switch to a market economy. Fruit production and trade were also heavily changed by Poland's accession to the European Union in 2004. The most important factor influencing the pace and direction of the changes was the agricultural policy. The state used a series of actions taken independently or under the EU assistance programmes (such as SAPARD, 2004-2006 RDP and 2007-2013 RDP) to help fruit growing and support its development. The financial means offered by those programmes contributed to the modernisation of the systems of fruit production and storage in Grójec poviat, and accelerated the adaptation of farms to the new economic conditions.

Economic determinants, such as profitability and the level of consumption of fruit and fruit products, were also important in the changes to fruit growing. Between 2000 and 2012, fruit prices fluctuated, while production costs grew steadily, which often had an adverse impact on the profitability of fruit farms. One positive factor was the growing consumption of fruit. This, in turn, promoted an increase in the area taken up by orchards and the introduction of changes to the production system, while the growing consumer demand became an incentive to adapt the structure of fruit production to their requirements.

The pace and directions of changes in fruit production were also heavily affected by the education of farm owners. Farms managed by people with proper professional qualifications and a sufficient level of knowledge concerning the cultivation of fruit trees and shrubs usually had better results than those run by unqualified people. Moreover, they more often decided to implement new technological solutions in the production and storage of fruit. Growers in Grójec poviat have adequate qualifications, therefore their farms are well-developed.

In the analysed period, significant changes occurred in the spatial structure of fruit production caused by the expanding area of orchards. A greater concentration of fruit crops can be recorded in communes involved in fruit growing for many generations, as well as in areas where fruit production is new. Changes also took place 
in the size structure of individual farms: their average size decreased, but this was no obstacle for the spatial and technological advancement of orchard production.

The spatial development of fruit production as well as its growing intensity resulted in an increase in the amount of fruit produced. While 600,000 tonnes were produced in 1994, the overall production exceeded 900,000 tonnes in 2010. Apples were the dominant group of fruit both before and after 2000. The organisation of fruit sale also saw important changes. Before the political transformation, the sale and further distribution of fruit in Grójec poviat was handled by cooperatives. After their break-up, wholesale markets became an important sale direction, besides purchasing centres. After Poland's accession to the European Union, foreign export also became important for producers in the poviat. The removal of barriers in foreign trade between EU member states facilitated the sale of fruit abroad. The dominant recipients of the sale of fruit in Grójec poviat are purchasing centres.

\section{References}

Agricultural Census 1996.

Agricultural Census 2010.

AIJN, 2010. European Fruit Juice Association, Liquid Fruit Market Report.

AIJN, 2012. European Fruit Juice Association, Liquid Fruit Market Report.

Balmann A., Dautzenberg K., Haooe K., Kellermann K., 2006. On the dynamics of structural change in agriculture. Internal frictions, policy threats and vertical integration. Outlook on Agriculture 35 (2): 115-121.

Bański J., Stola W., 2002. Przemiany struktury przestrzennej i funkcjonalnej obszarów wiejskich w Polsce (Changes in the spatial and functional structures of rural areas in Poland). Studia Obszarów Wiejskich 3, Warszawa.

Blandford D., Hill B., 2005. Structural change and public policies in EU agriculture: an overview. $\mathrm{XI}^{\text {th }}$ Congress of the European Association of Agricultural Economists, "The future of Europe in the global agri-food system", August 24-27, 2005. Copenhagen, Denmark.

Borowska A., 2013. Zmiany na rynku jabłek w Polsce z uwzględnieniem jabłek regionalnych (Changes in the apple market in Poland in terms of regional apples). Roczniki Ekonomiki Rolnictwa i Rozwoju Obszarów Wiejskich 100 (1): 152-167.

Csaki C., Jambor A., 2009. The diversity of effects of EU membership on agriculture in new member states. Policy Studies on Rural Transition. FAO Regional Office for Europe and Central Asia 4.

Czapiewski K., Janc K., 2009. Przestrzenne zróżnicowanie poziomu wykształcenia rolników. Europa-Polska-Mazowsze (Spatial differences in the level of education of farmers. Europe-Poland-Mazovia). Studia Obszarów Wiejskich- Proces przeksztatceń przestrzeni wiejskiej 27: 21-32.

Czernyszewicz E., Adamska A., 2008. Wsparcie finansowe wybranych gospodarstw sadowniczych na Lubelszczyźnie z funduszy Unii Europejskiej (Financial support for selected orchard farms in the Lublin region from EU funds). Zeszyty Naukowe Szkoty Głównej Gospodarstwa Wiejskiego w Warszawie. Problemy Rolnictwa Światowego 4(19): 105-114.

Czyżewski A., Smędzik-Ambroży K., 2015. Specialization and diversification of agricultural production in the light of sustainable development. Journal of International Studies 8(2): 63-73.

Freshfel Fruit and Vegetable Production, Trade, Supply \& Consumption Monitor in the EU, 2012.

Galanopoulos K., Nilsson F.O.L., Wajnblom E., Surry Y., 2009. Fruit and vegetable production in the new millennium. Will Mediterranean production satisfy increasing European demand? Outlook on Agriculture 38(3): 235-242.

Goldberg M., 1939. Monografia rolnicza powiatu grójeckiego (Agricultural monograph of Grójec poviat). Warszawa.

Gołasa P., 2014. Changes in European Union support of Polish organic fruit growing. Acta Scientiarum Polonorum. Oeconomia 13(2): 61-70.

Hinton L., 1977. Outlook for horticulture in Europe. Outlook on Agriculture 9(3): 108-113.

Hubbard C., Podruzsik S., Hubbard L., 2007. Structural change and distribution of support in Hungarian agriculture following EU accession: A preliminary FADN analysis. 104th Seminar on Agricultural Economics and Transition: „What was expected, what we observed, the lessons learned". September 6-8, 2007. Budapest, Hungary.

Hunek T., 2000. Teoria pozytywnej polityki agrarnej $\mathrm{w}$ modelowaniu polskiego rolnictwa (Theory of a positive agrarian policy in modelling Polish agriculture). In: Hunek T. (ed.), Dylematy polityki rolnej. Integracja polskiej wsi i rolnictwa $z$ UE. FAPA, Warszawa.

Izdebski W., Krupa K., Kupczyk A., Skudlarski J., Zając S., 2012. Audyt wykorzystania funduszy Unii Europejskiej $\mathrm{w}$ gospodarstwach sadowniczych w Polsce (Use of EU funds by orchard farms in Poland). Проблеми теорії та методології бухгалтерського обліку, контролю і аналізу. Вип 2 (23): 97-105.

Jankowski E., 1923. Dzieje ogrodnictwa w Polsce (History of horticulture in Poland). Nakładem Banku dla Handlu i Przemysłu w Warszawie, Warszawa.

Kacprzak E., 2002. Zmiany przestrzenno-organizacyjne sadownictwa w Polsce (Spatial-organisational changes in orcharding in Poland). Bogucki Wydawnictwo Naukowe, Poznań.

Kacprzak E., 2005. Zmiany przestrzenno-strukturalne polskiego sadownictwa w latach 1988-2004 (Spatial-organisational changes in Polish orcharding in the years 1988-2004). In: Głębocki B. (ed.), Struktura przestrzenna rolnictwa Polski u progu XXI wieku. Bogucki Wydawnictwo Naukowe, Poznań: 193-217.

Kiss J., 2011. Some impacts of the EU accession on the new member states' agriculture. Eastern Journal of European Studies 2(2): 49-60.

Kubiak K., 1998. Ekonomika i organizacja gospodarstw ogrodniczych (Economics and organisation of horticultural farms). Wydawnictwa Szkolne i Pedagogiczne, Warszawa.

Kulikowski R., 2007. Ogrodnictwo w Polsce. Rozmieszczenie, struktura upraw i rola w produkcji rolniczej (Horticul- 
ture in Poland. Distribution, crop structure and role in agricultural production). Przegląd Geograficzny 79(1): 79-98.

Lange E., Mika A., Czynczyk A., Cianciara Z., 1996. Program rozwoju sadownictwa $w$ najbliższym dziesięcioleciu dostosowany do wymogów światowych w zakresie produkcji owoców ziarnkowych (Programme of horticultural development in the nearest decade). I Ogólnopolskie Spotkanie Sadowników w Grójcu: Grójec 30-31 stycznia 1996. Instytut Sadownictwa i Kwiaciarstwa, Skierniewice: 1-12.

Makosz E., 2014. Polskie jabłka (Polish apples). Available at: http:/ / www.e-sadownictwo.pl/ startowa/2828-polskie-jablka (accessed 29 Dec. 2014).

Maliszewski M., 2004. Potencjał produkcyjny jabłek w rejonie grójeckim i planowane kierunki ich zagospodarowania (Production potential of apples in the Grójec region and planned directions of their use). IX Ogólnopolskie Spotkanie Sadowników w Grójcu - Szanse polskich sadowników przed wejściem do Unii Europejskiej. Instytut Sadownictwa i Kwiaciarstwa, Skierniewice: 49-56.

Mora R., San Juan C., 2004. Geographical specialisation in Spanish agriculture before and after integration in the European Union. Regional Science and Urban Economics 34(3): 309-320.

Nosecka B., 2005. Produkcja owoców i warzyw - informacje dla producentów (Production of fruits and vegetables: information for producers). Polska wieś w Europie. Instytut Ekonomiki Rolnictwa i Gospodarki Żywnościowej, Warszawa.

Pachocki S., 1997. Historia sadownictwa w rejonie grójecko-wareckim (History of orcharding in the Grójec-Warka region). II Ogólnopolskie Spotkanie Sadowników w Grójcu. Instytut Sadownictwa i Kwiaciarstwa, Skierniewice: 1-2.

Pieczyński B., 1996. Działania sadowników rejonu grójecko-wareckiego w zakresie zorganizowania rynku zbytu owoców (Operations of fruit growers of the Grójec-Warka region in organising a fruit market). I Ogólnopolskie Spotkanie Sadowników w Grójcu. Instytut Sadownictwa i Kwiaciarstwa, Skierniewice: 13-17.

Pieniążek S., 1965. Sadownictwo: podręcznik dla studentów akademii rolniczych (Fruit growing: A manual for students of agricultural academies). Państwowe Wydawnictwo Rolnicze i Leśne, Warszawa.

Pizło W., 2011. Economic situation of the Polish fruit growers in the period 1999-2009. Acta Scientiarum Polonorum. Oeconomia 10(3): 123-134.

Płocharski W., 2003. Wymagania w produkcji i obrocie owocami w Unii Europejskiej (Requirements in the production and sale of fruits in the European Union). XLII
Ogólnopolski Zjazd Sadowników. Instytut Sadownictwa i Kwiaciarstwa, Skierniewice: 38-87.

Rabbinge R., Diepen C.A., 2000. Changes in agriculture and land use in Europe. European Journal of Agronomy 13: 85-110.

Roman M., Nuszkiewicz K., 2013. Changes in agricultural production in Poland after accession to the European Union. Zeszyty Naukowe SGGW w Warszawie. Problemy Rolnictwa Światowego 13(28) 4: 156-161.

Skórnicki H., 1998. Restrukturyzacja produkcji sadowniczej $\mathrm{w}$ regionie grójecko-wareckim (Restructuring of fruit production the Grójec-Warka region). III Ogólnopolskie Spotkanie Sadowników w Grójcu. Instytut Sadownictwa i Kwiaciarstwa, Skierniewice: 96-101.

Skórnicki H., 2003. SAPARD dla sadowników (SAPARD for fruit growers). VIII Ogólnopolskie Spotkanie Sadowników w Grójcu - Nowoczesne sady szansa dla polskich sadowników w Unii Europejskiej. Instytut Sadownictwa i Kwiaciarstwa, Skierniewice: 5-13.

Słowińska B.A., 2007. Początki sadownictwa w Grójeckiem (Beginnings of fruit growing in the Grójec region). HORTPRESS Sp. z o.o., Warszawa.

Smoleń M., Górniak E., 2007. Interwencjonizm państwowy $w$ warunkach rynkowych (State intervention in market conditions). Wydawnictwo Oświatowe FOSZE, Rzeszów.

Statistical Yearbooks of Agriculture 2007, 2009, 2011, 2013. Central Statistical Office.

Vosta M., 2012. Agriculture under the conditions of globalisation focused on the expansion of the EU. Agriculture Economics - Czech. 58(4): 165-171.

Wicki L., 2005. Dynamika i efekty ukierunkowania gospodarstw rolniczych (Dynamics and effects of farm specialisation). In: Kłodziński M., Dzun W. (eds), Rolnictwo a rozwój obszarów wiejskich. IRWiR PAN, Warszawa: 82-92.

Wigier M., 2014. The competitiveness of Polish agriculture after accession to the EU. Economics of Agriculture 1: 87102.

Zegar J.S., 2009. Kwestia koncentracji ziemi w polskim rolnictwie indywidualnym (Question of land concentration in Polish individual farming). Rocznik Nauk Rolniczych, Seria G 96(4): 256-266.

Ziętara W., 2012. Pozycja konkurencyjna polskich gospodarstw rolnych $\mathrm{w}$ procesie integracji i globalizacji (Competitive position of Polish farms in the processes of integration and globalisation). Journal of Agribusiness and Rural Development 2(24): 297-308.

Żmija D., 2011. Dylematy dotyczące aktywnej roli państwa w obszarze rolnictwa (Dilemmas concerning an active role of the state in agriculture). Zeszyty Naukowe Uniwersytetu Ekonomicznego w Krakowie 863: 55-68. 